\title{
Editor's Report for Volume 124 (2010)
}

Mailing dates for issues in volume 124:

(1) 19 April 2011;

(2) 25 May 2011;

(3) 25 July 2011 ;

(4) 18 August 2011

A summary of distribution of memberships in the Ottawa Field-Naturalists' Club and subscribers to The Canadian Field-Naturalist for 2010 is given in Table 1. The number of articles and notes in Volume 124 is summarized in Table 2 by topic; totals for Book Reviews and New Titles are given in Table 3, and the distribution of content by page totals per issue in Table 4. Manuscripts excluding book reviews, notices, and reports] submitted to The Canadian Field-Naturalist totalled 56 in 2010 all of which were processed to various stages during the year; 21 of these were accepted for 2010 issues along with 23 first submitted in 2009, two first submitted in 2002, and one each in 2004 and 2005, all revised in 2010.

The journal was printed once again at Gilmore Printers, Ottawa, and thanks are due Chuck Graham for overseeing production and printing. As they have for many years now, Elizabeth Morton proofed and edited manuscripts, Wendy Cotie typeset galleys and corrections for page proofs, and prepared pdfs, Roy John requested books for review, selected reviewers, edited submitted reviews, and prepared the new titles listings. Sandra Garland, the webmaster for the Ottawa FieldNaturalists' Club, posted tables of contents and abstracts and some full pdfs on the OFNC website pending development and completion of the new Canadian FieldNaturalist web site by Jay Fitzsimmons. Leslie Cody again prepared the Index with proof-reading by Frank Pope who carried out all other duties of the Business Manager as well as serving as Club Treasurer. Jim Ward continued to mail invoices and reprints as Assistant Treasurer until he handed his duties on to Jay Fitzsimmons. My gratitude is due to all on this effective team.

The following reviewed papers submitted in 2010 (with number of manuscripts reviewed in parentheses if more than one).
Associate Editors: R. Anderson, Canadian Museum of Nature, Ottawa, Ontario; W. B. Ballard, Texas Tech University, Lubbock, Texas (13); C. D. Bird, Erskine, Alberta (9); R. R. Campbell, St. Albert, Ontario; P. M. Catling, Agriculture and Agri-Food Canada, Ottawa, Ontario (6); B. W. Coad, Canadian Museum of Nature, Ottawa, Ontario (2); A. J. Erskine, Sackville, New Brunswick (7); D. F. McAlpine, New Brunswick Museum, Saint John, New Brunswick (2); D. W. Nagorsen, Mammalia Biological Consulting, Victoria, British Columbia (7);

Others: L. G. Adams, USGS-Alaska Science, Anchorage, Alaska; R. Alvo, Ottawa, Ontario; K. B. Aubry, USDA Forest Service, Pacific Northwest Research Station, Olympia, Washington; M. Barret, Edmonton, Alberta; J. Bart, Snake River Field Station, USGS Forest and Rangeland Ecosystem Science Center, Boise, Idaho; M. Bechard, Boise State University, Idaho; R. Bedford, Ottawa, Ontario; S. Blaney, Atlantic Canada Conservation Data Centre, Sackville, New Brunswick; M. Boeckner, Meritus University, New Brunswick; R. Brooks, University of Guelph. Ontario; M. Boeckner, Meritus University, New Brunswick; D. Brunton, Ottawa, Ontario; L. Carbyn, Canadian Wildlife Service, Edmonton, Alberta; C. Cariappa. Texas Tech University, Lubbock, Texas; T. E. Chubbs, Department of National Defence, Happy Valley-Goose Bay, Labrador; D. Cluff, Environment and Natural Resources of the Northwest Territories, Yellowknife, Northwest Territories (2); M. Collins, Memorial University of Newfoundland, St. Johns; J. Cosgrove, Royal British Columbia, Museum, Victoria, British Columbia; S. Davis, Canadian Wildlife Service, Regina, Saskatchewan; S. DeStefano, University of Massachusetts, Amherst; J. DeVault, U.S. Department of Agriculture, Sandusky, Ohio; H. Dodds, Ontario Veterinary College, University of Guelph, Ontario; C. Edge, University of New Brunswick, Fredericton; P. Ewins, World Wildlife Fund Canada, Toronto, Ontario; R. Erickson, Texas Tech University, Lubbock, Texas; A. Ferguson, Texas Tech University, Lubbock, Texas;

TABLE 1. The 2010 circulation of The Canadian Field-Naturalist (2009 in parenthesis). Compiled by Frank Pope from the mailing list for 124(4).

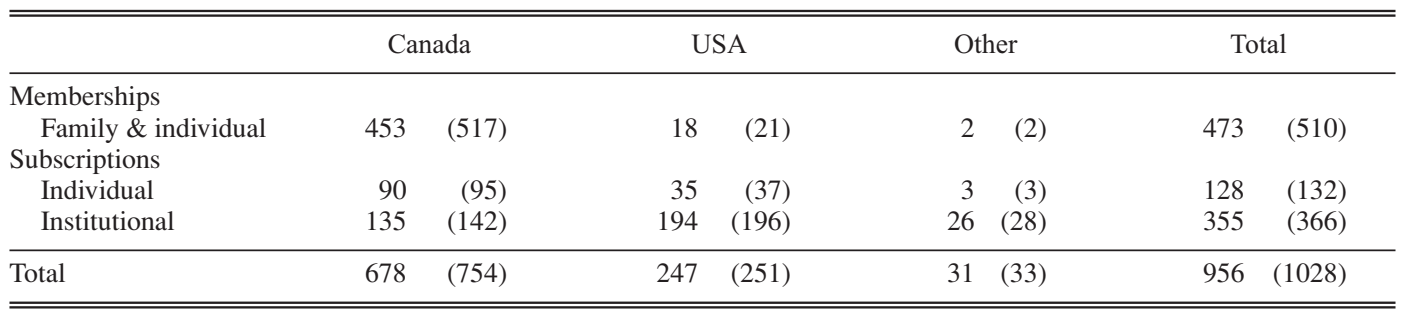


TABLE 2. Number of research and observation articles and notes published in The Canadian Field-Naturalist, Volume 124 (2010), by major field of study.

\begin{tabular}{lccr}
\hline \hline Subject & Articles & Notes & Total \\
\hline Mammals & 7 & 7 & 14 \\
Birds & 6 & 3 & 9 \\
Amphibians and reptiles & 4 & 1 & 5 \\
Fish & 2 & 1 & 3 \\
Plants & 5 & 2 & 7 \\
Other & 2 & 1 & 3 \\
\hline Total & 26 & 15 & 41 \\
\hline \hline
\end{tabular}

TABLE 3. Number of reviews and new titles published in the Book Review section of The Canadian Field-Naturalist, Volume 124, by topic.

\begin{tabular}{lcc}
\hline \hline & Reviews & New Titles \\
\hline Zoology & 15 & 33 \\
Botany & 3 & 10 \\
Environment & 7 & 9 \\
Miscellaneous & 2 & 4 \\
Electronic & 2 & 0 \\
\hline Total & 29 & 56 \\
\hline \hline
\end{tabular}

P. Frame, University of Alberta, Edmonton, Alberta; J.-M. Gagnon, Canadian Museum of Nature, Ottawa, Ontario; V. Geist, Port Alberni, British Columbia; J. Gilhen, Nova Scotia Museum of Natural History, Halifax, Nova Scotia (3); G. Gillespie, Fisheries and Oceans Pacific Biological Station, Nanaimo, British Columbia; L. Gillespie, Canadian Museum of Nature, Ottawa, Ontario; A. Giordano, Texas Tech University, Lubbock, Texas; J. M. Green, Memorial University of Newfoundland, St. John's; P. Gregory. University of Victoria, British Columbia; D. Gummer, Western and Northern Service, Centre, Parks Canada, Calgary Alberta: G. T. Hvenegaard, University of Alberta, Augustana Campus, Camrose, Alberta; D. Hebert, Creston, British Columbia; T. Herman, Acadia University, Wolfville, Nova Scotia; E. Holm, Royal Ontario Museum, Toronto, Ontario; D. Holt, Texas Tech University, Lubbock, Texas; T. S. Jung, Yukon Department of Environment, Whitehorse, Yukon Territory; C. Krebs, University of British Columbia, Vancouver; C. Kukal, Texas Tech University, Lubbock, Texas; R. Leach, Northern Alberta Institute of Technology, Edmonton; M. Mallory, Canadian Wildlife Service, Iqaluit, Nunavut; N. Mandrak, Fisheries and Oceans Canada, Burlington. Ontario; T. Meier, Denali National Park and Preserve, Alaska; A. Mercier, Memorial University, St. John's, Newfoundland and Labrador; D. F. Murray, University of Alaska Museum, University of Alaska Fairbanks; R. MacCulloch, Royal Ontario Museum, Toronto (3); D. Mech, U.S. Geological Survey, and The Raptor Center, University of Minnesota,
TABLE 4. Number of pages per section published in The Canadian Field-Naturalist, Volume 124 (2010), by issue.

\begin{tabular}{|c|c|c|c|c|c|}
\hline & \multicolumn{4}{|c|}{ Issue } & \multirow[b]{2}{*}{ Total } \\
\hline & 1 & 2 & 3 & 4 & \\
\hline Articles & 53 & 80 & 57 & 17 & 207 \\
\hline Notes & 7 & 4 & 22 & 0 & 33 \\
\hline Book Reviews* & 10 & 13 & 11 & 0 & 34 \\
\hline \multicolumn{6}{|l|}{ News and Comment, } \\
\hline Notice $^{* *}$ & 1 & 3 & 10 & 15 & 29 \\
\hline Tributes & 26 & 0 & 0 & 69 & 95 \\
\hline Index & - & - & - & 15 & 15 \\
\hline Advice to Contributors & 1 & 0 & 0 & 0 & 1 \\
\hline Total & 98 & 100 & 100 & 116 & 414 \\
\hline
\end{tabular}

* Total pages for book review section include both reviews and new titles listings.

** Includes CFN Editor's report in number 2, Minutes of the OFNC Annual Business Meeting in number 3, and OFNC Awards and review article in number 4.

St. Paul, Minnesota (7); D. Naughton, Canadian Museum of Nature, Ottawa, Ontario; R. Newell, E. C. Smith Herbarium, Acadia University, Wolfville, Nova Scotia; E. Nol, Trent University, Peterbourgh, Ontario; J. Oakleaf, U.S. Fish and Wildlife Service, Albuquerque, New Mexico; M. Panasci, Texas Tech University, Lubbock, Texas; K. G. Poole, Aurora Wildlife Research, Nelson, British Columbia; F. Pope, Ottawa, Ontario. H. Proctor, University of Alberta, Edmonton, Alberta; G. Proulx, Alpha Research \& Management Ltd., Sherwood Park, Alberta; M. Pybus, Alberta Fish and Wildlife Division, Edmonton; J. Reddoch, Ottawa, Ontario (3); C. Renaud, Canadian Museum of Nature, Ottawa, Ontario: E. M. Rominger, New Mexico Department of Game and Fish, Santa Fe, New Mexico; B. Samuel, Texas Tech University, Lubbock, Texas; J. Sanderson, Small Cat Conservation Alliance, Tucson, Arizona (2); J-P. L. Savard, Canadian Wildlife Service, Ste. Foy, Quebec; F. W. Schueler, Bishops Mills Natural History Centre, Ontario (4); C. Sheviak, New York State Museum at Albany (2); J. Skevington, Agriculture Canada, Ottawa, Ontario; P. Taylor, Acadia University, Wolfville, Nova Scotia; R. P. Thiel, Department of Natural Resources, Sandhills Wildlife Area, Babcock, Wisconsin; R. Thompson, Arizona Game and Fish Department. Phoenix; R. Weir, Artemis Wildlife Consulting, Armstrong, British Columbia; J. Whitaker Jr., Indiana State University, Terre Haute, Indiana; K. S. White, Alaska Department of Fish and Game, Douglas, Alaska; W. Wishart (retired) Alberta Fish and Wildife, Edmonton; M. Zinck Munro, Nova Scotia Museum, Halifax, Nova Scotia.

Since 1962, I am indebted above all to my wife Joyce who so successfully managed the difficult role of living with and encouraging an editor. In two terms as Editor (1962-1966; 1981-2010) I have edited a total of 19,479 journal pages in 137 issues in 34 1/4 years [a record for The Canadian Field-Naturalist, surpass- 
ing Harold Senn's 13 1/4 years, but not for a Canadian natural history journal, as Victor-A. Huard was editor of Le Naturalist canadien for 36 years; 1894-1929]. My thanks to present and past Presidents and Councils of the Ottawa Field-Naturalists' Club, especially to Chairman Ron Bedford and the Publications Committee (1981-2010) of the OFNC for support. The Canadian Museum of Nature (and its predecessor the National Museum of Canada) provided space and facilities during my tenure there as curator and researcher (1960-1993) and afterwards in retirement as emeritus and associate, most recently at the museum's Natural Heritage Building, Gatineau (Aylmer), Quebec. Thanks to the Associate Editors, and the many individual reviewers and the authors who submitted original articles, notes, reviews, and cover photos over the years, thus making the journal possible. The past contributions of these and others in production are acknowledged individually annually in my previous Editor's Reports (1982-2009) or in individual articles in The Canadian Field-Naturalist. Special thanks to the Ottawa Field-Naturalists' Club for the opportunity to edit their journal for so long, and to my initial editing predecessor and mentor, Bob Hamilton, and the editors between my two terms, Theodore Mosquin and Lorraine Smith, who are mainly responsible for the journal in its present form. I am indebted to the incoming Editor, Dr. Carolyn Callaghan, for making my transition out of the post both smooth and cordial.

FRANCIS R. COOK Past Editor 